\title{
Comparative Analysis of the Concept of Shakespearean Tragedies
}

\author{
Muhammad Aslam Sipra (Corresponding author) \\ JCC, King Abdulaziz University, Jeddah, Saudi Arabia \\ E-mail: aslamsipra@yahoo.com \\ Muhammad Haseeb Nasir \\ Department of English Studies, National University of Modern Languages, Islamabad, Pakistan \\ E-mail: nasirhaseeb87@gmail.com
}

Doi:10.7575/aiac.alls.v.5n.1p.31

URL: http://dx.doi.org/10.7575/aiac.alls.v.5n.1p.31
Received: 02/01/2014

Accepted: 24/02/2014

\begin{abstract}
In this article, the analysis of Shakespearean tragedies is presented. It reveals that Shakespeare's plays are full of conflicting thoughts, and expression is so convincing that it is not possible to plan a system of philosophy out of them. Each character, from the king to the clown, from the most highly intellectual to the simpleton, judges life from his own point of view and says something that is so deep and appropriate at the playwright's versatility of genius. So is the case with the conception of tragedy.
\end{abstract}

Keywords: Tragedies, comparative analysis, Shakespeare, plays, downfall, action, pity and fear

\section{Literature Review}

Prof. Thondrick (1908) says that Shakespeare uses elements of tragedy according to Aristotle's definition of tragedy. It could be first examined what Aristotle says in this context.

In Aristotle's Poetics (1961), tragedy is defined as the imitation of an action that is serious, has magnitude, complete in itself, in language with pleasurable accessories, each kind brought in a narrative form with incidents arousing pity and fear wherewith to accomplish its catharsis of such emotions.

Shakespeare in his earlier tragedies was, undoubtedly, influenced by Seneca but not in his major tragedies as Macbeth, Hamlet, Othello and King Lear but it is said that there would be no Elizabethan tragedy if there were no Seneca because Shakespearean themes are revenge, blood and thunder, rant and bombast madness, supernaturalism and sensationalism like that of Senecan plays. A. C. Bradley (2007) says that a Shakespearean tragedy may be called "a story of exceptional calamity of hero and heroine".

Romeo and Juliet can't be called a representative Shakespearean tragedy because Romeo and Juliet have no tragic flaw and only the tempest of circumstances wrecks their life. In Romeo and Juliet, the hero and the heroine are equally powerless. In Shakespeare's major tragedies, the hero is the central figure and the heroine fades in the twilight. As in Macbeth, the heroine appears only for a while and then she is pushed into the background. Some of the history plays of Shakespeare can also be called tragedies like Richard II and Richard III.

The action of tragedy should be the outcome of the conflict of will or will with circumstances. Shakespearean tragedy is always the outcome of conflict and conflict is always between new and his external world. The reason of this conflict is that man is not a paragon of perfection. Everyman has a tragic flaw as Cassius believes that everyman is responsible for his downfall although chances, accidents and fate are important to a great extent.

The fault dear Brutus is not in our stars but in ourselves that we are underlings

(Julius Caesar, I, ii, 140-141)

Conflicts both external and internal are the crux of Shakespearean tragedies as Evans (1999) says, "no conflict no drama".

Shakespeare's heroes possess errors which bring their doom. In Thompson and Taylor words (2006), Lear is violent, drastic effect, serious minded, Macbeth is too ambitious, Othello is jealous and Hamlet indulges in the procrastination, his mother's incestuous marriage shuns him and he cries out:

how weary, stale and flat and unprofitable, seem to me all the uses of this world

fie on it ah! Fie! 'tis an un-weeded garden" (Hamlet, I, ii, 133-34) 
Shakespearean tragic heroes as Othello, King Lear, Macbeth and Hamlet are always sick of life and in none of them can be found the glean of youthful vigour but his hero is always a person of high estate and noble stature and his sufferings are of his unusual kind. He is involved in agony and conflict owing to his own folly, weakness and blindness which has been called by critics as a tragic flaw. All the heroes of Shakespearean tragedy fulfill this demand of tragic hero. Romeo is an aristocratic, Macbeth is first a general and then a king, Othello is a general, Hamlet is a prince and King Lear is every inch a king. They are much above the average level of humanity but they are made of stuff we find within ourselves.

Shakespeare has introduced chance, accident and fate in his tragedies. In King Lear, it is a chance that Edgar arrives at prison too late to save Cordelia's death. In Hamlet, it is a chance that pirate ship attacks hamlet's ship and he discovers the intrigue of his uncle. It may be an accident that Romeo never got the Friar's message about the poison that Juliet did not awake from her long sleep. A minute sooner and Desdemona dropped her handkerchief at the most fatal of moments. Hamlet tries to kill the killer of his father but every time as Bradley (2007) writes, chance becomes a hindrance in his way as he says:

Now might I do it pat, now he is praying, now I shall do it

And so he goes to heaven. (Hamlet, III. iii, 77-78)

Some critics are of the view that in Shakespearean tragedies, it seems that only the jealously of gods, fate, chance and accidents are not responsible for their downfall but human wickedness and the human will to evil is also the cause of his doom because it the corruption of man's heart which turns Goneral and Regan into monsters. Similarly, villain Claudius as mentioned by French (2010) represents the spirit of the evil forces. Claudius villainous nature is revealed when Hamlet says:

That one may smile and smile and be a villain! (Hamlet, I. v. 104-5)

Shakespeare also introduces supernatural elements in his tragedies. The ghost and witches are an integral part of his tragedies. This element provides the confirmation and intensifies the movements in mind which are already present. Escolme (2012) writes about Hamlet's inward movements how they become strong by the revelation of ghost:

Do not forget: this visitation, Is but to...... But look,

Amazement on thy Mother sits. (Hamlet, III. iv, 110-12)

The use of subplot in Shakespearean tragedy also increases tragic effect and it is a common romantic expedient. Shakespeare oftenly uses subplot as an explanation of main theme as in hamlet play within play and in King Lear subplot universalizes the ingratitude and intensifies the tragic effect. Subplot reflects the duality of man's nature through its two protagonists Albany and Cornwall get equal share of kingdom from Lear, and Edgar and Edmund are equally dear to Gloucester and Hamlet catches the conscience of the king through play within play.

Aristotle (1961a) is of the view that the main object of tragedy is to arouse feelings of pity and fear. Shakespeare also creates this object. In King Lear, the misery and madness of Lear that he has no suitable shelter in spite of being a king enhances tragic effect and evokes our sense of pity. Similarly, when Gloucester's eyes were torn out, he wins our hearts. The death scene of Cordelia and King's remarks (Black, 2010) are very piteous when he says:

And my poor fool is hanged

No, no, no, life. (King Lear, V. iii. 311-12)

The question of nobility must be considered in this connection. Shakespeare has chosen villain heroes but every one of them is depicted high nobility. Hamlet accuses himself of cowardice:

$O$ what a rough and peasant

Slave am I." (Hamlet, II. ii. 555)

Lear's suffering is greater than his fault which enlarges his nobility as he says:

I a man more sinned against

Than sinning." (King Lear, III. ii. 59)

Likewise, Cordelia too suffers for her pride. Shakespeare also provides comic relief in his tragedies by using rhythmical verses of fool, grave-diggers, drunken potter and musilian. The grave diggers play pranks without realizing the situation. The fool provides so much comic relief as a safety valve for the emotions of the audience. Shakespeare maintains a unity of tone and effect in his tragedies. He rejects Aristotle's view that comic effect weakens the tragedy that is why it is said that Shakespeare's plots are loose because he does not follow the time, place and action according to Aristotle's definition.

Dr. Johnson (1929) defends Shakespeare of his non-observance of the unities of time, place and action. He argues that dramatic business is based on make believe. He says that audiences are conscious all the time they are looking at the stage. They know fully that stage is a stage and players are only players. Moreover, in tragic scenes, there remains no pleasure if we are not conscious that is merely a fiction. So he finds Shakespeare justified in having neglected the unities of time, place and action. 


\section{Discussion}

Now the important tragedies of Shakespeare are discussed. King Lear is one of the tragedies of character and the cause of his tragedy lies in Lear himself because he divides his kingdom between his two wicked daughters and ignores the sincere one. Lear's vanity is punished and readers feel that he suffers more than his sin. His tragedy is deepened by the storm scene and one feels that King Lear is a cosmic tragedy.

Hamlet has been rightly called a problem play. Masefield (2008) points out that nothing is simple and direct in Hamlet. Hamlet is a universal character. Hazlitt puts it this way that it is we who are Hamlet.

Hamlet's melancholy is his mother's hasty marriage with his uncle, his father's death, his suspicious nature and his love for Ophelia. That is why he is sick of his life. He says:

$O$ that this too too solid flesh would melt

Thaw and resolve itself into dew. (Hamlet. I. ii.129-30)

Another problem of Hamlet's tragedy is his madness which is not real. As A.C. Bradley says if Hamlet were really mad at any time in the story he would cease a tragic character. Hamlet himself tells Horatio that he is going to put on an antic disposition.

The most vexed question of Hamlet is his delay in taking revenge. His moral scruple nature intensifies his tragedy because he wants to know the fact of murder before doing something else, though he hates the marriage of his mother with his uncle Claudius. Hamlet is also a tragedy of character.

Othello is a tragedy of intrigue. A.C. Bradley (2007) expresses that Othello would have destroyed Iago's plot and ended his life but chance played a game and then both Othello and Desdemona were dead.

In Macbeth's character, the only tragic flaw is his inordinate ambition which brings his downfall.

The tragic heroes of Shakespeare are all lovely figures. They have no friends. Even heroes' wives and beloved have no favours of heroes. The hero dies and so does the heroine. Macbeth dies as does lady Macbeth. Romeo and Juliet die. Othello and Desdemona die. Hamlet and Ophelia die. Antony and Cleopatra die and Brutus and Portia die. The stage is littered with dead bodies, so one critic rightly suggests:

So many persons die of a disease called the last act of Shakespearean drama.

There is also a moral order in Shakespearean tragedy because the villain are always punished as Iago dies, Edmund, Goneril and Regan perish. Claudius can not escape death. It is said that in Shakespearean tragedies, there is no poetic justice because the good are not rewarded.

As Johnson says that he could never reconcile himself to the death of Cordelia. He says he was so shocked by Cordelia's death that he knows not whether he can endure if he reads again the last scenes of the play. Some critics are of the view that Cordelia was not able to live in this corrupt society, so the death of Cordelia is justified. Because the innocent people in their life often suffer greater sufferings while Cordelia's death is also Lear's punishment. Towards the end of the play, Lear triumphs over himself and the moral universe is triumphant over itself. In the beginning of Shakespearean tragedy, there may be a triumph of evil but the ultimate triumph of good is a fact in Shakespearean tragedies. We learn a lesson through the sufferings, miseries and calamities of Lear, Gloucester and Desdemona.

In King Lear, Lear's sufferings purify his mind and he achieves self-discovery. Similarly Gloucester leaves a message out of his sufferings. Cordelia's death also leaves a lesson behind and one feels that earthly happiness miseries are nothing but beside such love and devotion.

Therefore, a Shakespearean tragedy is never pessimistic. His tragedies prepare us for the immediate reaction. And we find ourselves more powerful to fight against our destiny, sufferings, miseries and hardships because Shakespeare's heroes share our common traits and we feel akin to them. Shakespeare's tragic heroes also have noble feelings and passions and also the embodiment of goodness and virtue.

In fact, Shakespearean tragedies are the tragedies of error. Shakespeare maintains a balance between everything, destiny and free will, between tragic effect and comic effect. Shakespeare uses simple and beautiful language in his tragedies. He uses similes and metaphors in a grand style and for suggesting his serious purposes.

To conclude, we can wind up our whole discussion with the view of Mr. Lucas that the motto of tragedy lies in Hamlet's words:

What a piece of work is a man! (Hamlet. II. ii. 295)

In fact, his uncle's unnatural act of murdering his father makes him a misanthrope that is why human being, despite being admirable creature, delights him not. Precisely, it is said that Hamlet is universal in appeal owing to its tragic appeal like all tragedies of Shakespeare. 


\section{References}

Black, J. L. (2010). The Broadview Anthology of British Literature, $2^{\text {nd }}$ edition: V.2: The Renaissance and the Early Seventeenth Century. Broadview Press: Canada

Bradley, A. C. (2007). Shakespearean Tragedy: Lectures on Hamlet, King Lear, Othello \& Macbeth, the Eco Library. Teddington: Middlesex

Butcher, S. H. (2008). Poetics. Cosimo, Inc: NY

Escolme, B. (2012). Talking to the Audience: Shakespeare, Performance and Self. Routledge, Abingdon: Oxon.

Evans, T. F. (1999). George Bernard Shaw: The critical heritage,.The Routledge: London.

French, A. L. (2010). Shakespeare and the critics. Cambridge University Press: NY.

Ingram A. (1998). Patterns of madness in $18^{\text {th }}$ century, Liverpool University Press: Liverpool

Johnson, S. (1929). Johnson on Shakespeare. Oxford University Press: London.

Jones, J. (2000). Shakespeare at work. Oxford University Press.

Mansfield, J. (2008). William Shakespeare: Hamlet, Prince of Denmark http://www.gutenberg.org/files/27264/27264h/27264-h.htm\#Page 157.

Thompson, A. \& Taylor, N. (2006). Hamlet. Arden Shakespeare: London.

Thorndike, A. H. (1908). Tragedy. The Riverside Press: Cambridge. 